\title{
MENINGKATKAN LOYALITAS PENGUNJUNG MUSEUM KONPERENSI ASIA AFRIKA MELALUI BRAND COMMUNITY SAHABAT MUSEUM (Survei Terhadap Member Sahabat Museum Konperensi Asia Afrika)
}

\author{
R. Desny Gita Kamilanovy \\ Suwatno \\ Manajemen Pemasaran pariwisata FPIPS UPI
}

\begin{abstract}
Bandung city to increase tourist arrivals from year to year. It is characterized by several factors such as the products and services of varied tourism, construction of access roads to tourist spots, and increased hotel construction and recreation. Bandung city tourism destinations have varied as culinary tours, shopping, heritage, and educational tours. Educational tours in the city no less a role in the tourism industry, one of which is a museum. One of the interesting tourist attraction in the city of Bandung Asian-African Conference Museum is the reference and study materials by the academic community in terms of the uniqueness of certain aspects of the documentation or the documentation and imaginative thinking in the future, this is done by the museum to maintain the loyalty of its visitors. Therefore the Asian-African Conference Museum visitors maintain loyalty through brand community Friends of the Museum consists of consciousness of kind of kind (brand awareness), rituals and tradition (ritual and tradition), and moral responsibility (feeling of responsibility). Based on the above then do research on brand loyalty is seen from the community. The unit of analysis of this study is the Asian-African Conference Museum visitors as loyal visitors who take the program brand community Friends of the Museum. The method used in this research is descriptive and verification, this study done in less than one year, then the method used is the cross sectional method. The data used are primary data and secondary data through literature study and a questionnaire. To measure the influence of brand community loyalty used multiple regression analysis, the aim of this research to determine the influence of brand community loyalty. Based on the results of the descriptive assessment 100 respondents who obtain the greatest value in the moral community brand responsibility. While the greatest value on the loyalty of the visits between product lines and services. In verifikatif brand community consists of consciousness of kind of kind (brand awareness), rituals and tradition (ritual and tradition), and moral responsibility (feeling of responsibility) may partially affect loyalty, different relations simultaneously based on the results of the analysis that the consciousness of kind have a negative influence on loyalty
\end{abstract}

Keyword: brand community and loyalty. 


\section{PENDAHULUAN}

\subsection{Latar Belakang}

Perkembangan pariwisata saat ini meningkat pesat karena adanya globalisasi yang didorong oleh kemajuan teknologi, informasi, dan sarana komunikasi yang cepat. Berbagai organisasi internasional antara lain PBB, Bank Dunia dan World Tourism Organization (WTO), telah mengakui bahwa pariwisata merupakan bagian yang tidak terpisahkan dari kehidupan manusia terutama menyangkut kegiatan sosial dan ekonomi.

Kegiatan yang semula hanya dinikmati oleh segelintir orang-orang yang relatif kaya pada awal abad ke-20, kini telah menjadi bagian dari hak azazi manusia, "where once travel was considered a privilege of the moneyed elite, now it is considered a basic human right" (sumber: Jhon Naisbitt, 2010: 122).

Pariwisata menghasilkan peluang yang besar untuk menyejahterakan masyarakat sealigus menghadisrkan tantangan dan ancaman pada komunitas lokal dan lingkungan. Perubahan iklim akan menjadi isu global yang berdampak besar pada pariwisata.

Tahun ke tahun Indonesia memiliki tingkat kunjungan wisatawan mancanegara yang fluktuaktif, hal tersebut dapat dilihat pada statistik kunjungan wisatawan di Indonesia pada Tabel 1.1

TABEL 1.1

STATISTIK KUNJUNGAN WISATAWAN DI INDONESIA 2004 - 2011

\begin{tabular}{|c|c|}
\hline TAHUN & $\begin{array}{c}\text { JUMLAH WISATAWAN } \\
\text { MANCANEGARA }\end{array}$ \\
\hline 2004 & 6.321 .165 \\
\hline 2005 & 6.002 .101 \\
\hline 2006 & 4.871 .361 \\
\hline 2007 & 6.606 .768 \\
\hline 2008 & 6.234 .487 \\
\hline 2009 & 6.323 .730 \\
\hline 2010 & 7.597 .186 \\
\hline 2011 & 7.649 .731 \\
\hline
\end{tabular}

Sumber: BPS, 2012

Tabel 1.1 menjelaskan bahwa jumlah kunjungan wisatawan mancanegara (wisman) ke Indonesia mengalami fluktuasi yang cukup signifikan. Pada tahun 2006 jumlah wisman mengalami penurunan sebanyak 1.130 .740 orang atau sebesar $18.8 \%$, sedangkan pada tahun 2008 wisatawan mengalami kenaikan yaitu sekitar 89.243 orang atau sebesar 1.43 $\%$. Pada tahun 2010 mengalami kenaikan jumlah wisatawan yaitu sebesar 1.273.256 wisatawan atau sebesar $20.1 \%$. Pada Tahun 2011 mengalami kenaikan lagi dengan jumlah wisatan sebesar 52.545 wisatawan atau sebesar $0,69 \%$, hal ini menunjukan bahwa kunjungan wisman ke Indonesia sangat signifikan. Kenaikan wisatawan bagi Indonesia menjadi suatu tantangan upaya mempertahankan jumlah kunjungan.
Negara dapat tumbuh dan berkembang menjadi negara maju dengan mengandalkan salah satu sektor pariwisata. Kota-kota besar banyak yang tergantung pada turis tantangan tersebut menjadi motivasi bagi Indonesia untuk menciptakan objek-objek wisata dalam negeri.

Indonesia kaya akan sumber daya alam dan budaya yang menarik wisatawan mancanegara untuk berkunjung. Berbagai destinasi yang tersebar di Indonesia menawarkan berbagai potensi wisata yang bervariasi. Salah satu destinasi yang memiliki sumber daya alam dan budaya yang sangat beragam adalah Provinsi Jawa Barat. Salah potensi wisata unggulan di provinsi ini adalah potensi wisata sejarah yang menarik dengan keunikan yang dimilikinya oleh setiap daerah di provinsi Jawa Barat. Salah satunya adalah 
Kota Bandung, Kota Bandung sebagai Ibu Kota provinsi Jawa Barat merupakan salah satu daerah yang memberikan kontribusi cukup besar dalam bidang pariwisata di Jawa Barat.

Pariwisata di Kota Bandung dapat dikatakan berkembang pesat hal tersebut terbukti dengan semakin banyaknya wisatawan yang berkunjung ke Kota Bandung, baik wisatawan nusantara (wisnus) maupun wisman. Sejak tahun 2006 hingga tahun 2008 wisatawan yang berkunjung terus mengalami kenaikan tertinggi terjadi pada tahun 2008 dengan jumlah 90.750, Namun pada tahun 2009 sempat mengalami penurunan dengan jumlah 537.773 wisatawan. Adapun jumlah wisatawan yang berkunjung ke Kota Bandung dapat dilihat secara lengkap pada Tabel 1.2.

TABEL 1.2

JUMLAH KUNJUNGAN WISATAWAN DI BANDUNG 2008-2010

\begin{tabular}{|c|r|r|r|}
\hline Tahun & $\begin{array}{c}\text { Jumlah } \\
\text { Wisatawan }\end{array}$ & $\begin{array}{c}\text { Wisatawan } \\
\text { Mancanegara }\end{array}$ & $\begin{array}{c}\text { Wisatawan } \\
\text { Nusantara }\end{array}$ \\
\hline 2008 & 4.495 .745 & 175.111 & 4.320 .634 \\
\hline 2009 & 5.007 .608 & 185.076 & 4.822 .532 \\
\hline 2010 & 5.179 .888 & 228.449 & 4.951 .439 \\
\hline
\end{tabular}

Sumber: Dinas Pariwisata Kota Bandung, Tahun 2010

Tabel 1.2 menjelaskan bahwa jumlah kunjungan wisatawan di Kota Bandung setiap tahunnya relatif meningkat, pada tahun 2010 Kota Bandung mampu meningkatkan kunjungan wisatawan hingga 172.280 atau sebesar 3,44 \%. Hal tersebut menyimpulkan bahwa Kota Bandung memiliki beberapa faktor seperti produk dan jasa pariwisata yang bervariasi, dibangunnya akses jalan menuju tempat wisata, dan bertambahnya pembangunan hotel dan tempat rekreasi. sebagai destinasi pariwisata yang berkembang pesat di Indonesia, Kota Bandung dihadapkan pada beberapa permasalahan. Media massa menyebutkan bahwa permasalahan yang terdapat di Kota Bandung meliputi kerusakan lingkungan akibat pencemaran udara, air, dan tanah, banjir, pembuangan sampah yang sembarangan, urbanisasi yang bertambah, lahan yang semakin sempit, pengabaian sumberdaya dan pelestarian hidup yang tidak menjadi prioritas sebagai destinasi pariwisata yang baik. (sumber: Kompas hal $7,16 / 11 / 2011$ ).

Salah satu daya tarik wisata yang menarik di Kota Bandung adalah museum yang menjadi referensi dan bahan studi oleh kalangan akademis dari segi aspek dokumentasi kekhasan masyarakat tertentu ataupun dokumentasi dan pemikiran imajinatif di masa depan.
Definisi dari museum berdasarkan definisi yang diberikan ICOM (International Council of Museums) merupakan institusi permanen nirlaba yang melayani kebutuhan publik, dengan sifat terbuka, dengan cara melakukan usaha pengoleksian, mengkonservasi, meriset, mengomunikasikan, dan memamerkan benda nyata kepada masyarakat untuk kebutuhan studi, pendidikan, dan kesenangan.

Program Tahun Kunjung Museum diikuti dengan rangkaian Gerakan Nasional Cinta Museum 2010-2014. Program ini terlihat sebagai upaya pemerintah untuk meningkatkan citra museum. Seperti yang dilihat pada Tabel 1.3 adalah program pemerintah tentang Museum.

\section{TABEL 1.3}

PROGRAM PEMERINTAH TENTANG MUSEUM

\begin{tabular}{|c|c|c|c|}
\hline & & \\
\hline No & Tahun & Program & Keterangan \\
\hline 1 & 2009 & $\begin{array}{c}\text { Visit } \\
\text { Museum } \\
\text { Year } 2010\end{array}$ & \begin{tabular}{lr}
\multicolumn{2}{l}{ Program ini dilakukan } \\
terhitung sejak 30 \\
Desember & 2009. \\
Program ini & terobosan \\
Asosiasi & Museum \\
Indonesia & (AMI) \\
bersama Kementerian \\
Kebudayaan \\
Pariwisata
\end{tabular} \\
\hline 2 & 2010 & $\begin{array}{l}\text { Gerakan } \\
\text { Nasional } \\
\text { Cinta } \\
\text { Museum } \\
2010- \\
2014\end{array}$ & \begin{tabular}{lr}
\multicolumn{2}{l}{ Program Museum ini } \\
adalah upaya tinak \\
lanjut dari program \\
Visit Museum Year \\
$2010, \quad$ diharapkan \\
menjadi \\
strategis langkah
\end{tabular} \\
\hline
\end{tabular}




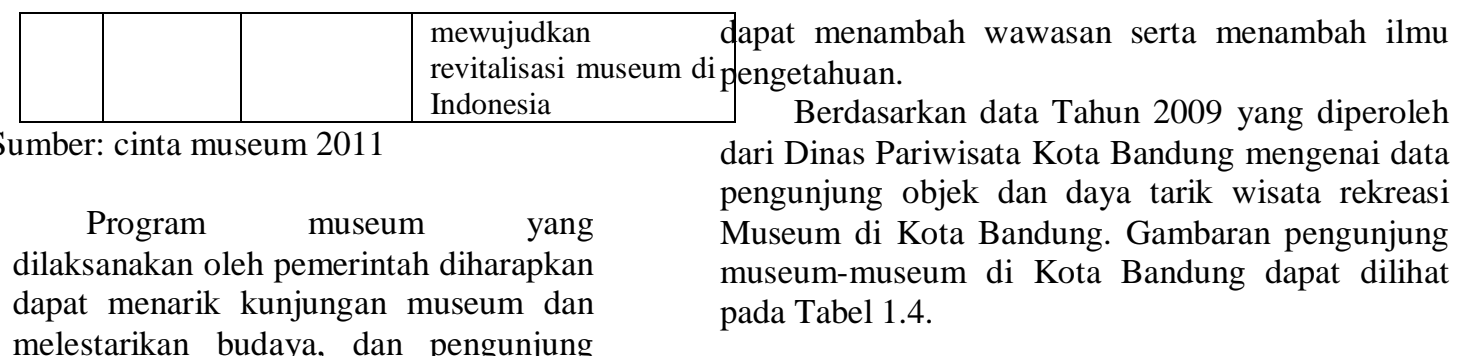

TABEL 1.4

PENGUNJUNG MUSEUM-MUSEUM DI KOTA BANDUNG 2007-2010

\begin{tabular}{|l|c|c|c|c|}
\hline \multicolumn{1}{|c|}{ Museum } & $\mathbf{2 0 0 7}$ & $\mathbf{2 0 0 8}$ & $\mathbf{2 0 0 9}$ & $\mathbf{2 0 1 0}$ \\
\hline Museum Geologi & 301173 & 289.414 & 650.591 & 400.726 \\
\hline Museum Margasatwa Taman Sari & - & 656.898 & 90.952 & 102.952 \\
\hline Museum Konperensi Asia Afrika & - & 109.971 & 113.956 & 168.354 \\
\hline Museum Sri Baduga & 110281 & 149.972 & 156.654 & 290.182 \\
\hline Museum Pos Indonesia & 19626 & 4.531 & 17.225 & 32.033 \\
\hline Museum Mandala Wangsit & 5767 & 325 & 20.878 & - \\
\hline Museum Barli & - & 4916 & 4.850 & 3,928 \\
\hline
\end{tabular}

Sumber: Kebudayaan dan Pariwisata Jawa barat 2011

Tabel 1.4 menjelaskan bahwa Kota Bandung berpotensi mempertahankan tingkat kunjungan di museum-museum Kota Bandung. Salah satu dari museummuseum pada Tabel 1.4 adalah Museum Konperensi Asia Afrika yang berada pada peringkat ketiga dengan jumlah pengunjung yang meningkat pada tahun 2008-2010, terutama peningkatan jumlah dari tahun 2009-2010 sebanyak 54.398 wisatawan.dengan demikian Museum Konperensi Asia Afrika memiliki potensi untuk mempertahankan dan meningkatkan kunjungan bersaing dengan museummuseum lainnya, dan mampu mengembangkan visinya yaitu "Sebagai museum bertaraf internasional dengan pengelolaan profesional."

Salah satu tujuan dari Museum Konperensi Asia Afrika adalah menunjuang usaha-usaha dalam rangka pengembangan kebudayaan nasioal, pendidikan generasi muda, dan peningkatan kepariwisataan. Berikut ini Tabel 1.5 adalah mengenai jumlah pengunjung wisatawan Museum Konperensi Asia Afrika Tahun 2008 - 2010.

TABEL 1.5

DATA PENGUNJUNG MUSEUM KONPERENSI

ASIA AFRIKA 2008-2011

\begin{tabular}{|c|c|c|c|c|}
\hline PENGUNJUNG & 2008 & 2009 & 2010 & 2011 \\
\hline TK / Play Group & - & - & 721 & $\overline{656}$ \\
\hline SD / MI & 10.987 & 12.807 & 20.942 & 21.185 \\
\hline SMP / MTs & 49.865 & 46.063 & 65.837 & 64.242 \\
\hline SMA / SMK / MA & 19.646 & 21.659 & 25.024 & 23.121 \\
\hline Perguruan Tinggi & 2.711 & 2.945 & 3.423 & 5.212 \\
\hline Peneliti & 159 & 257 & 86 & \\
\hline Wartawan & 54 & 104 & 117 & 63 \\
\hline Organisasi / Instansi Asing & 857 & 1.545 & 1.218 & 777 \\
\hline Organisasi / Instansi NonAsing & 5.009 & 6.715 & 9.829 & 6.293 \\
\hline Wisatawan Nusantara & 4.580 & 18.180 & 35.886 & 59.291 \\
\hline Wisatawan Mancanegara & 2.883 & 3.524 & 5.190 & 5.203 \\
\hline Tamu Negara & 273 & 157 & 81 & 142 \\
\hline
\end{tabular}




\begin{tabular}{|l|r|r|r|r|}
\hline JUMLAH & 10.9971 & 113.956 & 168.354 & 186.200 \\
\hline Persentase kenaikan & & $3.62 \%$ & $47.7 \%$ & $10.6 \%$ \\
\hline
\end{tabular}

Sumber: Museum Konperensi Asia Afrika 2012

Tabel 1.5 mengenai jumlah pengunjung Museum Konperensi Asia Afrika 2008 - 2010, memiliki jumlah kunjungan yang semakin meningkat. Tahun 2009 Museum Konperensi Asia Afrika mengalami kenaikan sebesar 3.985 pengunjung atau sebesar $3.62 \%$, pada tahun 2010 mengalami kenaikan yang sangat tinggi yaitu sebesar 543.398 pengunjung atau sebesar $47.7 \%$, dan pada tahan 2011 mengalami kenaikan sebesar $10.6 \%$ atau sebesar 17.846 pengunjung.

Tingkat kunjungan Museum Konperensi Asia Afrika dari tahun ke tahun mengalami kenaikan yang cukup signifikan, pengunjung yang semakin meningkat belum tentu merasa puas saat berkunjung ke museum. Museum Konperensi Asia Afrika memiliki target agar pengunjung merasa loyal setelah berkunjung ke Museum Konperensi Asia Afrika dengan melakukan program cinta museum melalui program Komunitas Sahabat Museum.

Komunitas Sahabat Museum Konperensi Asia Afrika terdiri dari berbagai macam golongan tua maupun muda diantaranya adalah pelajar, organisasi, pegawai swasta/negeri, dan lain-lain, komunitas ini semakin tahun semakin meningkat jumlah membernya, hal ini menjadi salah satu upaya Museum Konperensi Asia Afrika untuk berkomunikasi secara langsung dengan Komunitas sosial. Hubungan ini menjadi suatu keuntungan bagi museum karena komunitas Sahabat Museum dapat ikut membantu museum dalam segala bentuk event yang dilaksanakan oleh Museum Konperensi Asia Afrika, berikut adalah jumlah member komunitas Sahabat Museum Konperensi Asia Afrika dari tahun 2010 sampai dengan Tahun 2012.

TABEL 1.6

JUMLAH MEMBER KOMUNITAS SAHABAT MUSEUM KONPERENSI

ASIA AFRIKA

\begin{tabular}{|c|c|c|}
\hline No & Tahun & Jumlah Member \\
\hline 1 & 2010 & 270 \\
\hline 2 & 2011 & 365 \\
\hline 3 & 2012 & 487 \\
\hline
\end{tabular}

Sumber: Museum Konperensi Asia Afrika, 2012

Jumlah member yang semakin meningkat dari tahun ke tahun belum menunjukan bahwa member komunitas Sahabat Museum loyal terhadap museum
Konperensi Asia Afrika, dapat dilihat pada data kunjungan kegitan komunitas Sahabat Museum konperensi Asia Afrika Juni 2010 - Juli 2011:

TABEL 1.7

JUMLAH KUNJUNGAN KEGIATAN KOMUNITAS SAHABAT MUSEUM KONPERENI ASIA AFRIKA PER ENAM BULAN (2010 - 2012)

\begin{tabular}{|l|c|c|c|c|}
\hline \multirow{2}{*}{ SMKAA } & $\mathbf{2 0 1 0}$ & $\mathbf{2 0 1 1}$ & $\mathbf{2 0 1 1}$ & $\mathbf{2 0 1 2}$ \\
\cline { 2 - 5 } & $\begin{array}{c}\text { Juli s.d } \\
\text { Desember }\end{array}$ & $\begin{array}{c}\text { Januari s.d } \\
\text { Juni }\end{array}$ & $\begin{array}{c}\text { Juli s.d } \\
\text { Desember }\end{array}$ & $\begin{array}{c}\text { Januari s.d } \\
\text { Juni }\end{array}$ \\
\hline Movie Week & 310 & 332 & 313 & 307 \\
\hline Reading Club & 393 & 272 & 325 & 292 \\
\hline Gathering SMKAA & 223 & 215 & 211 & 201 \\
\hline JUMLAH & $926 \quad 1745$ & 819 & 849 & 794 \\
\hline Jumlah per tahun & \multicolumn{2}{|c|}{1643} \\
\hline
\end{tabular}

Sumber: Museum Konperensi Asia Afrika, 2012

Tabel 1.7 menunjukan bahwa jumlah kunjungan kegiatan komunitas sahabat museum mengalami naik turun setiap per enam bulannya, satu tahun petama yaitu Tahun 2010 Juli s.d Desember dan Tahun 2011 Januari s.d Juni jumlah kunjungan kegiatan 
komunitas Sahabat Museum sebesar 1745 kunjungan, dan pada tahun kedua yaitu Tahun 2011 Juli s.d Desmember dan Tahun 2012 Januari s.d Juni jumlah kunjungan kegiatan komunitas Sahabat Museum sebesar 1643 kunjungan. Jumlah kunjungan pada tahun kedua mengalami penurunan sebesar 5,85\%.

Keanggotaan Sahabat Museum terdiri dari pengunjung Museum Konperensi Asia Afrika melakukan lebih dari satu kali kunjungan. Repeat customers do not necessary exhibit true loyalty. There are true loyal. Customers and others who are not (Yuping Liu \& Rong Journal of marketing 2009: 226). Seperti yang dijelaskan oleh Yuping Liu dan Rong pengulangan kunjungan belum tentu pelanggan setia sejati, artinya wisatawan yang berkunjung ke Museum lebih dari satu kali belum tentu adalah wisatawan yang loyal.

Jika pengunjung telah memiliki kepuasan atas produk atau jasa yang diberikan oleh Museum Konperensi Asia Afrika, dibutuhkan dukungan dari lingkungan sosial pengunjung yang dapat menahan keinginan pengunjung untuk berganti pilihan ke Museum lain. Hal di atas akan berpadu pada diri pengunjung dan menciptakan tingkat loyalitas tertinggi dari konsumen seperti diutarakaan oleh oliver sebagai ultimate loyalty. (Sumber: Fajar Marta Kusumah, 2010:24).

Komunitas merek adalah sesuatu yang special, hubungan yang tak terbatas wilayahnya, berdasarkan kepada seperangkat struktur hubungan sosial diantara pecinta merek. (Sumber: Muniz dan O'Guinn (2004:58). Usaha untuk mendapatkan loyalitas pengunjung diperlukan strategi yang sulit dibandingkan menciptakan kepuasan konsumen, untuk mencapai loyalitas tertinggi diperlukan adanya komunitas sosial sebagi perlindungan dari serangan persaingan (Sumber: Oliver. 1999: 67)

Museum Konperensi Asia Afrika perlu melakukan pendekatan perilaku, karena pengunjung menginginkan kepuasan dan pengalaman yang optimal, melalui pendekatan tersebut diharapkan dapat mengetahui keinginan pengunjung kemudian dapat meningkatkan loyalitas pengunjung, hal ini dapat dilihat pada jumlah kegiatan Sahabat Museum pada Tahun ke-2 menagalami penurunan. Brand community dalam Museum menjadi sarana untuk mengetahui keinginan dari setiap pengunjung, karena komunitas museum adalah pengunjung yang paling intens dan pasar yang paling potensial. Dengan dipahaminya keinginan pengunjung maka diharapkan dapat loyalitas pengunjung Museum Konperensi Asia Afrika.

Berdasarkan latar belakang penelitian tersebut maka perlu diadakan suatu penelitian tentang "Meningkatkan Loyalitas Pengunjung Museum Konperensi Asia Afrika Melalui Brand Community Sahabat Museum" (survey terhadap Komunitas Sahabat Museum Konperensi Asia Afrika)

\subsection{Rumusan Masalah}

Berdasarkan latarbelakang di atas, maka rumusan masalah penelitian sebagai berikut:

1. Bagaimanakah brand community Sahabat Museum Konperensi Asia Afrika.

2. Bagaimana loyalitas pengunjung Museum Konperensi Asia Afrika.

3. Bagaimana pengaruh brand community terhadap loyalitas pengunjung.

\subsection{Tujuan Penelitian}

1. Untuk mengetahui gambaran brand community Sahabat Museum Konperensi Asia Afrika.

2. Untuk menganalisis loyalitas pengunjung Museum Konperensi Asia Afrika

3. Untuk menganalisis brand community terhadap loyalitas pengunjung.

\subsection{Kegunaan Penelitian}

1. Kegunaan Teoritis

Secara teoritis hasil penelitian ini diharapkan dapat menambah serta memperluas kajian ilmu pemasaran pariwisata, khususnya mengenai brand community dalam meningkatkan loyalitas pengunjung di Museum Konperensi Asia Afrika.

2. Kegunaan Praktis

Secara praktis hasil penelitian ini diharapkan dapat memberikan masukan kepada Museum Konperensi Asia Afrika mengenai pengaruh 
brand community terhadap loyalitas pengunjung sehingga dapat menjadi informasi bagi pihak terkait dalam upaya untuk meningkatkan jumlah kunjungan pada Museum Konperensi Asia Afrika.

\section{KERANGKA PEMIKIRAN}

\subsection{Kerangka Pemikiran}

Industri pariwisata saat ini semakin bersaing dimana hal ini penting untuk sebuah perusahaan jasa termasuk instansi pemerintahan salah satunya adalah museum. Pemasaran merupakan cara untuk mempromosikan dan mendistribusikan jasa untuk memuaskan pengunjung (W. Y. Stanton, 2009:55), sedangkan pemasaran dalam pariwisata merupakan sistem yang dilaksanakan oleh instansi pemerintah atau lembaga pariwisata lainnya sebagai alat untuk mencapai kepuasan pengunjung dan memenuhi kebutuhan pengunjung untuk mencapai keuntungan (W. Y Stanton dalam Oka A. Yoeti, 2005:1). Museum Konperensi Asia Afrika merupakan instansi pemerintah yang mengharapkan pengunjung mencapai kebutuhannya, dan di samping itu juga mencapai keuntungan yang wajar berupa pencitraan yang baik bagi Museum.

Pemasaran museum di adopsi dari teori pemasaran dimana Museum memiliki sistem dan koordinasi yang dilaksanakan seperti perusahaan-perusahaan lainnya. Museum Konperensi Asia Afrika memiliki sistem pemasaran yang melibatkan masyarakat atau komunitas sosial. Karena masyarakat atau komunitas sosial sebagai alat pembantu yang berperan penting untuk mempromosikan jasa kepada pengunjung museum, pemasaran melalui proses kemasyarakatan menciptakan jasa yang bernilai (Kotler \& Keller, 2009:5) Metode pemasaran museum adalah mendengarkan keinginan dan kebutuhan pengunjung, dan mengetahui faktor-faktor apa saja bahwa museum dapat menjadi hal yang menarik bagi pengunjung (Journal of Tourism. Marketing museum. Hull, 2010:7). Museum harus melakukan strategi dalam mencapai tujuannya.yaitu melalui tiga langkah dalam pemasaran museum yaitu segmenting, targeting, dan positioning (Kotler \& Keller, 2009:28)

Museum Konperensi Asia Afrika merupakan sebuah institusi pemerintahan yang menawarkan layanan jasa kepada masyarakat, maka pendekatan dan strategi pemasaran dapat diterapkan oleh Museum. Keahlian dari pemasar yang professional dapat menciptakan, memelihara, dan meningkatkan merek. Merek sebagai pembeda barang dan jasa museum dengan kompetitornya (Kotler, 2000:41). Pada intinya merek adalah pengguna nama, logo, trade mark, serta slogan untuk membedakan museum-museum datu sama lain dalam hal apa yang mereka tawarkan. Merek dalam penelitian ini adalah Museum Konperensi Asia Afrika, dengan demikian merek mengandung tiga hal, yaitu menjelaskan apa yang dijual museum, apa yang dijalankan museum, dan profil museum itu sendiri.

Brand community bagian dari Destination branding yang merupakan komunitas yang terkoordinasi kedekatannya dengan produk atau jasa museum. Brand community merupakan bentuk komunitas yang terspesialisasikan yang memiliki ikatan, tidak berbasis geografis, namun lebih berdasar pada hubungan sosial pada museum (Muniz dan O'Guinn, 2001: 413). Brand community adalah kelompok sosial yang memiliki persamaan komitmen pada produk/ jasa tertentu, merek dan aktivitas kunjungan.(Schouten \& Alexander, 2005:36).

Komunitas dapat menjadi beberapa pengertian seperti lokasi geografis, keanggotaan pada organisasi sosial tertentu, dan sekumpulan individu yang memiliki perasaan dan karakteristik yang sama (Herek dan Glunn, 2007;28). Sense of community sebagai presepsi kesamaan, dan keyakinan setiap individunya merupakan bagian dari struktur yang luas (Sarason: 2005:44).

Museum mendukung adanya aktivitas dan memfasilitasi terbentuknya komunitas, harapan dari strategi ini adalah bahwa museum memperoleh hubungan dengan jangka waktu yang panjang dengan pengunjung yang dapat mewujudkan loyalitas pengunjung terhadap museum (Berry dan Paruraman, 2001:31). Pada brand community terdapat consumer community yang merupakan alat yang menghubungan setiap individu dalam komunitas dengan museum,dan sebagai alat yang berperan penting dalam membangun 
dalam membangun merek atau citra museum itu sendiri (Philip Kotler, 2003:68). Komunitas mrek dapat terjadi pada saat pengunjung museum berkunjung dan mendapatkan pelayanan jasa yang di berikan museum (Kevin Keller, 2006:55).

Manfaat dari brand community bagi pengunjung yaitu pengunjung dapat memiliki keuntungan seperti mendapatkan informasi, ilmu pengetahuan, dan hubungan sosial. Sedangkan bagi Museum adalah meningkatkan hubungan jangka panjang museum dengan pengunjung atau relasi jangka panjang, hubungan ini dapat membantu museum untuk mengetahui kebutuhan dan keinginan pengunjung dari museum (Mark Resmick, dalam Fajar M.K. 2010:58). Pembangunan citra yang baik pada saat komunitas melaksanakan kegiatan atau aktivitas yang berhubungan dengan Museum Konperensi Asia Afrika.

Brand Community memiliki beberapa komponen yaitu (Muniz \& O'guinn 2001:417) yaitu Conciousness of kind (kesadaran bersama), Ritual and tradition (Ritual dan tradisi) dan Moral responsibility (rasa bertanggung jawaab).

Conciousness of kind atau kesadaran bersama, hal ini terlihat jelas dalam komunitas. Setiap anggota dalam komunitas merasa hubungannya dengan merek itu penting, dan merasa bahwa mereka saling mengenal antar sesame anggota walaupun mereka belum pernah bertemu. Terdapat indicator dari conciusness of kind diantaranya lengitimacy yaitu proses dimana anggota komunitas membedakan antara anggota komunitas dengan yang bukan anggota komunitas, atau memiliki hak yang berbeda. Hal ini tidak selalu ada pada setiap komunitaas, tetapi anggot dapat membedakan siapapun yang loyal terhadap merek tersebut dapat dikatakan menjadi anggota komunitas. Yang kedua yaitu Opposotional brand loyalty adalah proses sosial yang terlibat selain kesadaran masyarakat atas seuatu jenis produk (Conciousness of kind). Melalui oposisi dalam kompetisi merek berfungsi untuk menggambarkan apa yang bukan merek dan siapakah yang bukan anggota komunitas merek.

Ritual and tradition merupakan proses sosial yang penting di mana arti komunitas itu adalah mengembangkan dan menyalurkan dalam komunitas. Ritual dan tradisi dalam komunitas merek berfungsi untuk mempertahankan tradisi budaya komunitas. Ritual dan tradisi yang dilakukan diantaranya, celebrating the history of brand yaitu menanamkan sejarah dalam komunitas juga melestarikan budaya. Yang kedua sharing brand stories berbagi cerita pengalaman menggunakan produk atau jasamerek adalah hal yang penting untuk menciptakan dan menjaga komunitas.

Moral responsibility atau rasa bertanggung jawab. Tanggung jawab moral yang dilakukan ini adalah hasil kolektif yang dilakukan dan memberikan kontribusi pada rasa kebersamaan dalam kelompok, rasa tanggung jawab moral ini menjadi kewajiban setiap anggota komunitas. Ada dua hal penting dan misi umum tradisional yaitu integrating and retaining members atau integraasi dan memperhatikan anggota, dalam kehidupan tradisional memperhatikan kehidupan umum, perilaku yang konsisten dianggap sebagai dasar tanggung jawab keanggotaan komunitas.yang kedua assisting in the use of the brand bantuan ini merupakan komponen penting dari komunitas, bantuan ini salah satu cara perwujudan diri sendiri, bantuan itu sendiri melalui tindakan untuk membantu sesama anggota komunitas memperbaiki produk/ jasa memecahkan masalah.khususnya yang melibatkan pengetahuan yang diperoleh melalui pengalaman menggunakan merek.

Terdapat empat karakteristik terbentuknya komunitas merek, yaitu; (1) brand image, mendefinisikan bentuk komunitas museum, (2) aspek hedonis, lebih pada ekspresi, pengalaman dan hedonis, (3) sejarah, pengunjung yang berbagi apresiasi tentang museum atau yang berhubungan dengan sejarah museum, (4) persaingan yang tinggi, persaingan antar museum mendorong terbentuknya loyalitas komunitas museum terhadap museumnya (Davidson et al, dalam Fajar M.K., 2010:60).

Setiap komunitas pada organisasi tertentu dalam teori pemasaran ini berdasarkan pada merek tertentu, seperti halnya dalam penelitian ini komunitas merek diaplikasikan pada museum menjadi komunitas sahabat museum. Komunitas sahabat museum merupakan kunci keberhasilan bagi museum (Holmes, 2003:201). Sahabat museum adalah alat pemasaran museum melalui memberl anggota, dan cara museum menawarkan layanan jasanya dengan inofatif untuk pengunjung dan bertindak 
mendukung kegiatan museum (Goodlad \&Mclvor, 2008:203).

Program sahabat museum mempromosikan segala bentuk kegiatan museum melalui kegiatan belajar, rekreasi secara gratis, hal ini menjadi asset museum dalam memasarkan layanan jasa yang bervariatif ditawarkan oleh museum, pengunjung dapat memilih apa yang mereka butuhkan pada museum sesuai dengan minat mereka (Orr, 2006:206)

Sahabat Museum Konperensi Asia Afrika adalah sebuah brand community yang dibentuk oleh Museum Konperensi Asia Afrika yang tergolong ke dalam dua kategori kegiatan, yaitu: (1)exhibition temporary, pameran sederhana yang dirancang oleh sahabat museum Konperensi Asia Afrika yang berkaitan dengan sejarah, seni dan budaya. (2)Educational program, pengunjung dan member melakukan kunjungan untuk studi, mendapatkan informasi yang dibutuhkan, dan mendapatkan ilmu pengetahuan. Kegiatan ini didukung dengan fasilitas untuk kegiatan edukasinya.

Brand community dibentuk agar Museum mengetahui keinginan pengunjung, karena pengunjung yang berpartisipasi dalam komunitas Sahabat Museum akan memberikan gambaran bagi Museum tentang keinginan pengunjung, dan memberikan pencitraan yang baik pula untuk Museum. Brand community sebagai alat untuk membantu Museum untuk mencapai tujuannya, diantaranya yaitu mengetahui keinginan pengunjung, memberikan kepuasan terhadap layanan jasa yang diberikan, serta meningkatkan kesetiaan pengunjung terhadap Museum Konperensi Asia Afrika, hal ini mendorong Museum ke dalam pencitraan yang baik.

Konsep loyalitas pengunjung lebih banyak dikaitkan dengan perilaku dari pada dengan sikap dan seseorang pengunjung yang loyal akan memperlihatkan perilaku kunjungan yang dapat didefinisikan sebagai kunjungan non random yang diungkapkan dari waktu ke waktu oleh beberapa untit pengambilan keputusan (Griffin, 2009:5). Pengunjung yang loyal akan melakukan kunjungan ulang, karena telah berkomitmen untuk melakukan kunjungan kembali, meskipun situasi pemasaran selalu berubah terhadap perilaku setiap pengunjung (Oliver dalam Hurriyati, 2010:128).

Loyalitas pengunjung dapat terwujud dengan cara membangun hubungan yang kuat dan menjaikan hubungan yang dekat dengan pengunjung sehingga terjadi komunikasi antara keduanya saling mengetahui dengan tetap menjaga hubungan yang baik dengan pengunjung walaupun pengunjung tidak sedang berkunjung ke museum. Pengunjung akan merasa diperhatikan sehingga tentunya Museum akan mendapatkan keuntungan jika memiliki pengunjung yang tingkat loyalitasnya tinggi, pengunjung yang loyal akan menunjukan ciriciri yang merupakan dimensi dari loyalitas itu sendiri seperti yang dikemukakan oleh Griffin (2009:3) yang terdiri dari melakukan kunjungan secara teratur, melakukan kunjungan lini atau produk dan jasa, mereferensikan kepada orang lain, menunjukan kekebalan dari daya tarik produk sejenis dari psaing.

Brand Community mempunyai hubungan yang erat dan mempengaruhi kepuasan pengunjung, yang pada akhirnya kepuasan pengunjung mempengaruhi loyalitas serta dampak dari brand community terhadap loyalitas pengunjung akan membantu Museum untuk mengukur sejauh mana program brand community terhadap pengunung (Philipp Wiegandt, 2009:72). Griffin (2009:4) mengatakan loyalitas disarkan pada perilaku dan didefinisikan sebagai pembelian non random diungkapkan dari waktu ke waktu oleh beberapa unit pengambilan keputusan berkunjung. Pengunjung yang memperoleh kepuasan dalam brand community murupakan modal dasar bagi museum dalam membentuk loyalitas pengunjung. Pengunjung yang loyal adalah asset yang paling berharga alam meningkatkan profitabilitas museum.

Berdasarkan kerangka pemikiran, maka dapat diketahui paradigm penelitianpengaruh brand community terhadap Loyalitas, maka bentuk paradigm penelitian ini dapat dilihat pada Gambar 2.1: 


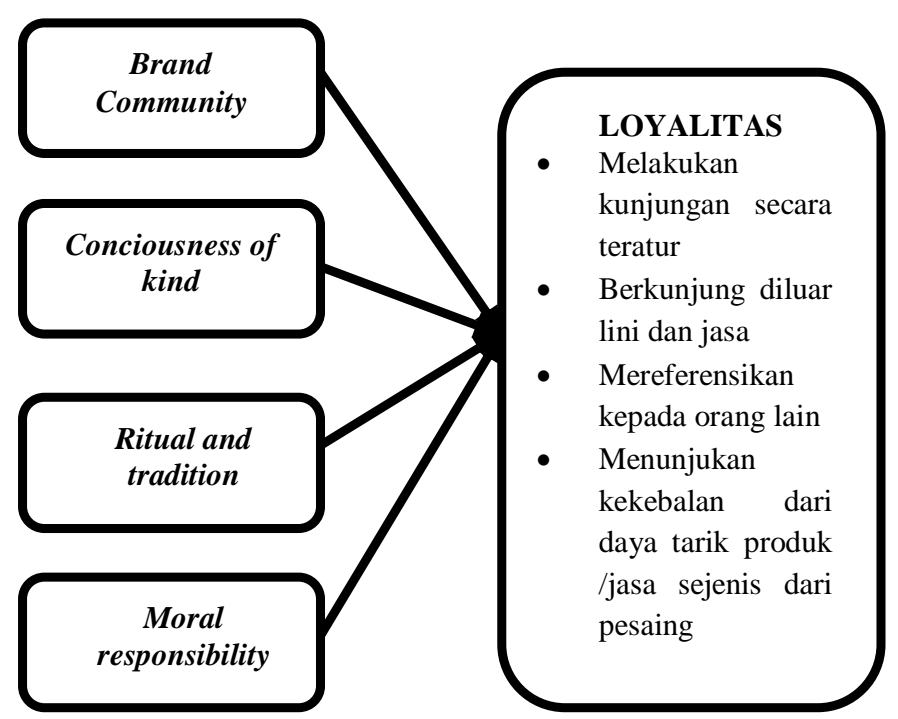

GAMBAR 2.1

PARADIGMA PENELITIAN

\subsection{Hipotesis Penelitian}

Hipotesis merupakan jawaban sementara terhadap masalah penelitian yang dibangun berdasarkan kerangka teoritis tertentu yang kebenarannya perlu diuji secara empiris. Hipotesis mrupakan jawaban sementara terhadap rumusan masalah penelitian (Sugiono, 2009:221). Dikatakan sementara karena jawaban yang diberikan baru didasarkan pada teori yang relevan, belum didasarkan pada fakta-fakta yang empiris yang diperoleh melalui pengumpulan data.

Pada bagian ini akan menguji hipotesis meningkatkan Loyalitas pengunjung melalui

\section{METODE PENELITIAN}

\subsection{Objek Penelitian}

Penelitian ini menganalisis mengenai pengaruh strategi brand community terhadap loyalitas pengunjung Museum Konperensi Asia Afrika. Adapun yang menjadi objek penelitian sebagai variabel bebas (independent variable) adalah strategi brand community. Variabel bebas yaitu brand community meliputi consciousness of kind, rituals and tradition, dan moral responsibility.

Pada penelitian ini, objek yang dijadikan responden adalah pengunjung
Brand Community pada Museum Konperensi Asia Afrika. sehingga dapat ditarik sebuah hipotesis "Terdapat pengaruh yang signifikan antara brand community terhadap loyalitas pengunjung Museum Konperensi Asia Afrika.”

Perumusan hipotesis didukung oleh premis dari beberapa penelitian, berdasarkan kerangka pemikiran dan paradigma penelitian diperoleh premis-premis yaitu sebagai berikut:

1. Berdasarkaan penelitian sebelumnya adanya hubungan antar variabel brand community dan loyalitas merek adalah kuat menuju sangat kuat serta merupakan hubungan yang positif. (Heng chiang huang, 2007: 41)

2. Brand community merupakan faktor pendorong penting dari loyalitas dan mungkin lebih penting dari kepuasan (Chaudhry dan Krishnan, 2007: 208).

3. Program komunitas merek pada perusahaan dapat meningkatkan loyalitas merek konsumen (Jang et al, 2004: 291). Konsep "konsumen" yang dimaksud dalam penelitian ini adalah "pengunjung:

4. Selain menumbuhkan loyalty terhadap sebuah merek, brand community juga dapat menjadi co-creation antara perusahaan dan konsumen mereka. Karena dengan adanya brand community, maka konsumen dapat ikut memberikan ide-ide baru untuk meningkatkan kualitas produk perusahaan tersebut. (Philipp Wiegand, 2009:72). Perusahaan yang dimaksud dalam penelitian ini adalah Museum.

museum Konperensi Asia Afrika. Dalam hal ini penulis akan mengkhususkan pada salah satu strategi pemasaran melalui brand community. Hal ini agar Museum Konperensi meningkatkan loyalitas pengunjung di Museum Konperensi Asia Afrika. Adapun variabel terikat (dependendent variable) adalah loyalitas yaitu melakukan kunjungan secara teratur, berkunjung diluar lini dan jasa, mereferensikan kepada orang lain, dan menunjukan kekebalan dari daya tarik produk /jasa sejenis dari pesaing.

Dari kedua objek penelitian ini maka dapat dianalisis: pertama mengukur pelaksanaan brand 
community Museum Konperensi Asia, kedua mengukur tanggapan responden mengenai loyalitas berkunjung, dan mengukur tanggapan responden mengenai pengaruh brand community Museum Konperensi Asia Afrika terhadap tingkat loyalitas pengunjung.

\subsection{Metode Penelitian}

3.2.1 Jenis dan Metode yang Digunakan

Berdasarkan variabel-variabel yang diteliti, maka metode penelitian yang digunakan dalam penelitian ini adalah metode deskriptif dan verifikatif. Penelitian deskriptif menurut Sugiyono (2010:35), "penelitian deskriptif adalah penelitian yang tidak membuat perbandingan variabel dengan variabel lain". Penelitian deskriptif disini bertujuan untuk memperoleh gambaran mengenai brand community dan loyalitas pengunjung.

Adapun sifat dari penelitian ini adalah verifikatif yaitu suatu penelitian yang akan digunakan untuk menguji kebenaran dari suatu hipotesis (Suharsimi, 2008:7). Penelitian ini akan menjelaskan kejelasan hubungan yang terjadi antara variabel independen (X) dan variabel dependen (Y) sekaligus menguji kebenaran. Dalam hal ini, diuji mengenai pengaruh brand community terhadap loyalitas pengunjung.

Berdasarkan hal tersebut, penelitian ini bersifat deskriptif dan verifikatif yang dilaksanakan melalui pengumpulan data di lapangan, maka metode penelitian yang akan digunakan adalah metode explanatory survey. Survey informasi dari sebagian populasi (sampel responden) dikumpulkan langsung di tempat kejadian secara empirik, dengan tujuan untuk mengetahui pendapat dari sebagian populasi terhadap objek yang sedang diteliti. Menurut Kerlinger, yang dikutip oleh Sugiyono (2010:7), yang dimaksud dengan metode survei, yaitu metode penelitian yang dilakukan pada populasi besar maupun kecil, tetapi data yang dipelajari adalah data dari sampel yang diambil dari populasi tersebut, sehingga ditemukan kejadian-kejadian relatif. Distribusi dan hubungan-hubungan antar variabel sosiologis maupun psikologis.

Adapun penelitian ini dilakukan dalam jangka waktu kurang dari satu tahun oleh karena itu metode yang digunakan adalah cross sectional method. Menurut Husein Umar (2009:42), cross sectional method yaitu metode penelitian dengan cara meneliti suatu fenomena tertentu dalam satu kurun waktu saja.

Menurut Uma Sekaran (2006:315), penelitian cross sectional adalah penelitian dimana data dikumpulkan hanya sekali yang dilakukan selama periode hari, minggu, atau bulan untuk menjawab pertanyaan penelitian.

Berdasarkan objek penelitian di atas yang menjadi variabel bebas adalah pelaksanaan brand community yang terdiri dari dua 3 variabel yaitu consciousness of kind, rituals and tradition, dan moral responsibility. Sedangkan yang merupakan variabel terikat yaitu adalah loyalitas pengujung yang terdiri dari melakukan kunjungan secara teratur, berkunjung diluar lini dan jasa, mereferensikan kepada orang lain, dan menunjukan kekebalan dari daya tarik produk /jasa sejenis dari pesaing.

Variabel loyalitas tersebut digunakan untuk mengukur dan menganalisis tingginya pengaruh pelaksanaan brand community yang dilaksanakan Museum Konperensi Asia Afrika. Dari variabelvariabel tersebut dapat dioperasionalisasikan dalam Tabel 3.1 berikut ini: 
TABEL 3.1

OPERASIONALISASI VARIABEL

\begin{tabular}{|c|c|c|c|c|}
\hline $\begin{array}{c}\text { Variabel/ } \\
\text { Sub } \\
\text { Variabel }\end{array}$ & Konsep Variabel & Indikator & Ukuran & Skala \\
\hline 1 & 2 & 3 & 4 & 5 \\
\hline $\begin{array}{l}\text { Brand } \\
\text { Communit } \\
y \\
(\mathbf{X})\end{array}$ & \multicolumn{4}{|c|}{$\begin{array}{l}\text { "Brand community adalah suatu bentuk komunitas yang terspesialisasi, komunitas } \\
\text { yang memiliki ikatan yang tidak berbasis pada ikatan secara geografis, namun lebih } \\
\text { didasarkan pada seperangkat struktur hubungan sosial diantara penggemar merek } \\
\text { tertentu" (Muniz \& O’Guinn: 2001:418) }\end{array}$} \\
\hline \multirow[t]{3}{*}{$\begin{array}{l}\text { Concius } \\
\text { ness of } \\
\text { kind }\end{array}$} & \multirow{3}{*}{$\begin{array}{l}\text { Kesadaran } \\
\text { masyarakat atas } \\
\text { suatu jenis produk/ } \\
\text { jasa, yang terlihat } \\
\text { dalam komunitas } \\
\text { (Muniz \& O'Guinn, } \\
\text { 2001:418) } \\
\text { pada ukuran } \\
\text { tambahkan } \\
\text { "sejauhmana } \\
\text { menetahui ttg } \\
\text { sejarah museum } \\
\text { kaa" } \\
\text { Dan } \\
\text { "Sejauhmana } \\
\text { tingkat } \\
\text { kesadaranfukung } \\
\text { kelestari museum } \\
\text { kaa" }\end{array}$} & $\begin{array}{l}\text { Kesadaran masyarakat atas } \\
\text { suatu jenis produk/ jasa, yang } \\
\text { terlihat dalam komunitas } \\
\text { (Muniz \& O’Guinn, 2001:418) }\end{array}$ & $\begin{array}{l}\text { Memiliki rasa } \\
\text { kedekatan dengan } \\
\text { Museum } \\
\text { Konperensi Asia } \\
\text { Afrika }\end{array}$ & Ordinal \\
\hline & & $\begin{array}{l}\text { Mengetahui Gambar, merek, } \\
\text { logo dari komunitas Sahabat } \\
\text { Museum dan Museum } \\
\text { Konperensi Asisa Afrika }\end{array}$ & $\begin{array}{l}\text { Sejauh mana } \\
\text { mengetahui } \\
\text { Gambar, merek, } \\
\text { logo dari } \\
\text { komunitas } \\
\text { Sahabat Museum } \\
\text { dan Museum } \\
\text { Konperensi Asisa } \\
\text { Afrika }\end{array}$ & Ordinal \\
\hline & & $\begin{array}{l}\text { Mengetahui jenis produk dan } \\
\text { jasa Sahabat Museum } \\
\text { Konperensi Asia Afrika yang } \\
\text { ditawarkan oleh }\end{array}$ & $\begin{array}{l}\text { Sejauh mana } \\
\text { mengetahui jenis } \\
\text { produk dan jasa } \\
\text { Sahabat Museum } \\
\text { Konperensi Asia } \\
\text { Afrika yang }\end{array}$ & Ordinal \\
\hline \multirow[t]{3}{*}{$\begin{array}{l}\text { Rituals } \\
\text { and } \\
\text { Tradition }\end{array}$} & \multirow{3}{*}{$\begin{array}{l}\text { Rutual dan tradisi } \\
\text { merupakan proses } \\
\text { sosial yang penting } \\
\text { di mana arti } \\
\text { komunitas itu } \\
\text { adalah } \\
\text { mengembangkan } \\
\text { dan menyalurkan } \\
\text { dalam komunitas } \\
\text { (Muniz \& O’Guinn, } \\
\text { 2001:418) }\end{array}$} & $\begin{array}{l}\text { Sering mengikuti kegiatan } \\
\text { yang diselenggarakan oleh } \\
\text { Sahabat Museum Konperensi } \\
\text { Asia Afrika }\end{array}$ & $\begin{array}{l}\text { Tingkat rutinitas } \\
\text { mengikuti } \\
\text { kegiatan yang } \\
\text { diselenggarakan } \\
\text { oleh Sahabat } \\
\text { Museum } \\
\text { Konperensi Asia } \\
\text { Afrika }\end{array}$ & Ordinal \\
\hline & & $\begin{array}{l}\text { Selalu berbagi cerita dengan } \\
\text { sesama anggota mengenai } \\
\text { pengalaman berkunjung ke } \\
\text { Museum konperensi Asia } \\
\text { Afrika }\end{array}$ & $\begin{array}{l}\text { Tingkat rutinitas } \\
\text { berbagi cerita } \\
\text { dengan sesama } \\
\text { anggota mengenai } \\
\text { pengalaman } \\
\text { berkunjung ke } \\
\text { Museum } \\
\text { konperensi Asia } \\
\text { Afrika }\end{array}$ & Ordinal \\
\hline & & $\begin{array}{l}\text { Kemenarikan kegiatan yang } \\
\text { dilaksanakan oleh Sahabat } \\
\text { Museum Konperensi Asia } \\
\text { Afrika }\end{array}$ & $\begin{array}{l}\text { Tingkat } \\
\text { Kemenarikan } \\
\text { kegiatan yang } \\
\text { dilaksanakan oleh } \\
\text { Sahabat Museum }\end{array}$ & Ordinal \\
\hline
\end{tabular}




\begin{tabular}{|c|c|c|c|c|}
\hline & & & $\begin{array}{l}\text { Konperensi Asia } \\
\text { Afrika }\end{array}$ & \\
\hline & & $\begin{array}{l}\text { Keinginan untuk mengikuti } \\
\text { kegiatan/ event yang } \\
\text { dilaksanakan oleh Sahabat } \\
\text { Museum Konperensi Asia } \\
\text { Afrika }\end{array}$ & $\begin{array}{l}\text { Tingkat keinginan } \\
\text { untuk mengikuti } \\
\text { kegiatan/ event } \\
\text { yang dilaksanakan } \\
\text { oleh Sahabat } \\
\text { Museum } \\
\text { Konperensi Asia } \\
\text { Afrika }\end{array}$ & Ordinal \\
\hline \multirow[t]{6}{*}{$\begin{array}{l}\text { Moral } \\
\text { Responsib } \\
\text { ility }\end{array}$} & \multirow{6}{*}{$\begin{array}{l}\text { Tanggung jawab } \\
\text { moral adalah } \\
\text { memiliki rasa } \\
\text { tanggung jawab dan } \\
\text { berkewajiban secara } \\
\text { keseluruhan, serta } \\
\text { kepaada setiap } \\
\text { anggota komunitas } \\
\text { (Muniz \& O’Guinn, } \\
\text { 2001:418) }\end{array}$} & $\begin{array}{l}\text { Rasa harus memiliki ID card } \\
\text { member Sahabat Museum } \\
\text { konperensi Asia Afrika }\end{array}$ & $\begin{array}{l}\text { Tingkat rasa harus } \\
\text { memiliki ID card } \\
\text { member Sahabat } \\
\text { Museum } \\
\text { konperensi Asia } \\
\text { Afrika }\end{array}$ & Ordinal \\
\hline & & $\begin{array}{l}\text { rasa tanggung jawab untuk } \\
\text { ikut melestarikan Museum } \\
\text { Konperensi Asia Afrika }\end{array}$ & $\begin{array}{l}\text { Sejauh mana rasa } \\
\text { tanggung jawab } \\
\text { untuk ikut } \\
\text { melestarikan } \\
\text { Museum } \\
\text { Konperensi Asia } \\
\text { Afrika }\end{array}$ & Ordinal \\
\hline & & $\begin{array}{l}\text { kegiatan wisata di museum kaa } \\
\text { mmpengatuhi }\end{array}$ & $\begin{array}{l}\text { Sejauh mana } \\
\text { kegiatan wisata di } \\
\text { Museum }\end{array}$ & ordinal \\
\hline & & $\begin{array}{l}\text { tanggung jawab untuk } \\
\text { melestarikan Museum } \\
\text { Koperensi Asia Afrika. }\end{array}$ & $\begin{array}{l}\text { Konperensi Asia } \\
\text { Afrika } \\
\text { mempengaruhi } \\
\text { tanggung jawab } \\
\text { untuk } \\
\text { melestarikan } \\
\text { Museum } \\
\text { Konperensi Asia } \\
\text { Afrika }\end{array}$ & \\
\hline & & $\begin{array}{l}\text { kegiatan wisata yang } \\
\text { diselenggarakan oleh } \\
\text { komunitas dapat meningkatkan } \\
\text { rasa tanggung jawab utk } \\
\text { melestarikan Museum } \\
\text { konperensi Asia Afrika }\end{array}$ & $\begin{array}{l}\text { Sejauhmana } \\
\text { kegiatan wisata } \\
\text { yang } \\
\text { diselenggarakan } \\
\text { oleh komunitas } \\
\text { dapat } \\
\text { meningkatkan } \\
\text { rasa tanggung } \\
\text { jawab utk } \\
\text { melestarikan } \\
\text { Museum } \\
\text { konperensi Asia } \\
\text { Afrika. }\end{array}$ & Ordinal \\
\hline & & $\begin{array}{l}\text { Kepedulian terhadap kegiatan } \\
\text { yang dilaksanakan }\end{array}$ & $\begin{array}{l}\text { Tingkat } \\
\text { kepedulian } \\
\text { terhadap kegiatan }\end{array}$ & Ordnal \\
\hline
\end{tabular}




\begin{tabular}{|c|c|c|c|c|}
\hline & & & $\begin{array}{l}\text { yang } \\
\text { dilaksanakan. }\end{array}$ & \\
\hline \multirow[t]{2}{*}{$\begin{array}{l}\text { Loyalitas } \\
\text { (Y) }\end{array}$} & \multicolumn{4}{|c|}{$\begin{array}{l}\text { Suatu pola pembelian yang teratur dalam jangka waktu yang lama yang dilakukan } \\
\text { oleh unit-unit pembuat atau pengambilan keputusan. (Griffin, 2009:4). Pembelian } \\
\text { dalam penelitian ini diaplikasikan menjadi kunjungan. }\end{array}$} \\
\hline & $\begin{array}{l}\text { Melakukan } \\
\text { kunjungan secara } \\
\text { teratur }\end{array}$ & $\begin{array}{l}\text { Keinginan untuk mengunjungi } \\
\text { kembali Museum Konperensi } \\
\text { Asia Afrika }\end{array}$ & $\begin{array}{l}\text { - Tingkat } \\
\text { keinginan untuk } \\
\text { mengunjungi } \\
\text { kembali Museum } \\
\text { Konperensi Asia } \\
\text { Afrika } \\
\text { - Tingkat } \\
\text { kunjungan ulang } \\
\text { jasa dari kegiatan } \\
\text { brand community } \\
\text { Museum } \\
\text { Konperensi Asia } \\
\text { Afrika }\end{array}$ & Ordinal \\
\hline & $\begin{array}{l}\text { kunjungan antar lini } \\
\text { produk dan jasa }\end{array}$ & $\begin{array}{l}\text { Keinginan untuk } \\
\text { menggunakan layanan lain } \\
\text { selain brand community (klab } \\
\text { bahasa) }\end{array}$ & $\begin{array}{l}\text { - Tingkat } \\
\text { keinginan untuk } \\
\text { menggunakan } \\
\text { layanan lain } \\
\text { selain brand } \\
\text { community (klab } \\
\text { bahasa) } \\
\text { - Tingkat } \\
\text { keinginan untuk } \\
\text { menggunakan } \\
\text { kembali layanan } \\
\text { jasa selain brand } \\
\text { community (klab } \\
\text { bahasa) }\end{array}$ & Ordinal \\
\hline & $\begin{array}{l}\text { Mereferensikan } \\
\text { kepada orang lain }\end{array}$ & $\begin{array}{l}\text { Memberitahukan kepada rekan } \\
\text { untuk menjadi member } \\
\text { komunitas (brand community) }\end{array}$ & $\begin{array}{l}\text { - Tingkat } \\
\text { memberitahukan } \\
\text { kepada rekan } \\
\text { untuk menjadi } \\
\text { member } \\
\text { komunitas } \\
\text { Sahabat Museum } \\
\text { Konperensi Asia } \\
\text { Afrika (brand } \\
\text { community) }\end{array}$ & Ordinal \\
\hline & $\begin{array}{l}\text { Menunjukan } \\
\text { kekebalan dari daya } \\
\text { tarik produk sejenis } \\
\text { dari pesaing }\end{array}$ & $\begin{array}{l}\text { Keinginan untuk tetap } \\
\text { berkunjung di Museum } \\
\text { Konperensi Asia Afrika }\end{array}$ & $\begin{array}{l}\text { - Tingkat } \\
\text { keinginan untuk } \\
\text { tetap berkunjung } \\
\text { di Museum } \\
\text { Konperensi Asia } \\
\text { Afrika } \\
\text { - Tingkat } \\
\text { penolakan untuk }\end{array}$ & Ordinal \\
\hline
\end{tabular}




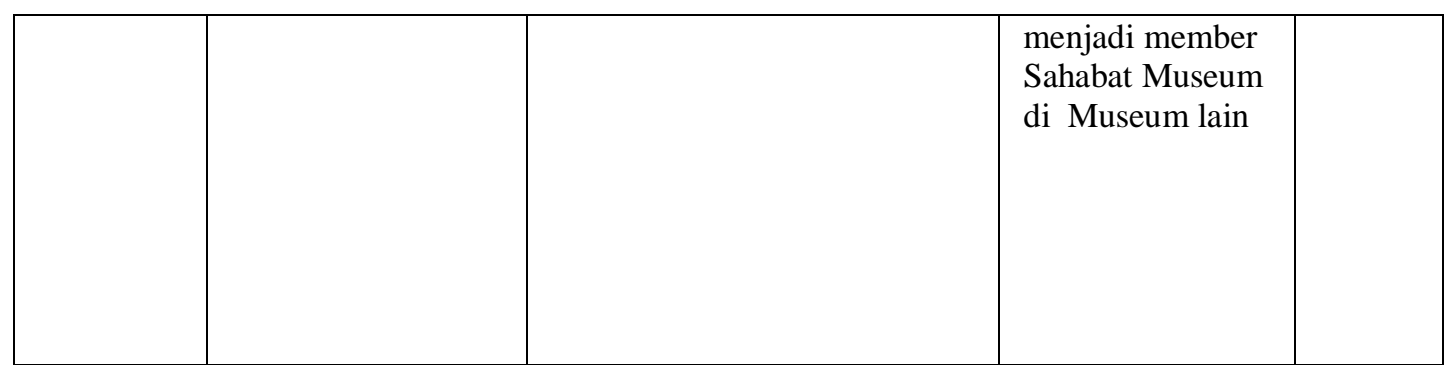

Sumber : Dimodifikasi dari berbagai literatur

\subsubsection{Metode Penarikan Sampel}

Sampel dalam penelitian ini adalah sebagian dari populasi penelitian, yaitu sebagian member Sahabat Museum Konperensi Asia Afrik pada tahun 2012. Data yang telah dimiliki berupa populasi sebesar 487 orang. Ukuran sampel tersebut diperoleh berdasarkan hasil perhitungan dengan menggunakan rumus Slovin.

\subsubsection{Prosedur Pengumpulan Data}

Pengumpulan data yang dilakukan penulis menggunakan teknik sebagai berikut:

1. Studi kepustakaan

2. Angket atau kuesioner

3. Wawancara

\subsection{Hasil Pengujian Validitas dan Reliabilitas \\ 3.3.1 Hasil Pengujian Validitas}

Berdasarkan hasil pengolahan data dengan menggunakan software komputer SPSS 20 menunjukkan bahwa item-item pertanyaan dalam kuesioner valid karena $r_{\text {hitung }}$ lebih besar jika dibandingkan dengan $r_{\text {tabel }}$ yang bernilai 0,374 .

\subsubsection{Hasil Pengujuian Reabilitas}

Pengujian reliabilitas inumen pada penelitian ini dilakukan dengan menggunakan software SPSS (Statistical Product for Service Solution) 20 for windows. Menurut Sekaran (2003:312) dalam jurnal Oka (2009:42) teknik pengujian reliabilitas menggunakan koefisien alpha cronbach dengan taraf nyata 5\%. Jika koefisien korelasi lebih besar dari nilai kritis atau jika nilai alpha cronbach lebih besar darpada 0,6 maka item tersebut dinyatakan reliabel, koefisien alpha kurang dari 0,6 menunjukan reliabilitaas yang buruk, angka sekitar 0,7 menunjukan reliabilitas yang buruk, angka sekitar 0,7 menunjukan reliabilitas dapat diterima dan angka di atas 0,8 menunjukan reliabilitas yang baik. berikut Tabel 3.2 uji reliabilitas instrumen penelitian:

TABEL 3.2

PENGUJIAN RELIABEILITAS INSTRUMEN PENELITIAN

\begin{tabular}{|c|l|c|c|c|}
\hline No & \multicolumn{1}{|l|}{ Variabel } & $\begin{array}{c}<\boldsymbol{r}_{\text {hitung }} \\
\text { (alpha) }\end{array}$ & $<\boldsymbol{r}_{\text {tabel }}$ & Keterangan \\
\hline 1 & $\begin{array}{l}\text { Brand } \\
\text { community }\end{array}$ & $\mathbf{0 , 8 5 7}$ & $\mathbf{0 , 7 0}$ & $\begin{array}{c}\text { Tingat reliabilitas tinggi karena nilai alpha } \text { cronbach } \geq \\
0,70 \text { dan mendekati angka 1 (satu) }\end{array}$ \\
\hline 2 & loyalitas & $\mathbf{0 , 7 6 2}$ & $\mathbf{0 , 7 0}$ & $\begin{array}{c}\text { Tingat reliabilitas tinggi karena nilai alpha } \text { cronbach } \geq \\
0,70 \text { dan mendekati angka 1 (satu) }\end{array}$ \\
\hline
\end{tabular}

Sumber: Hasil pengolahan data, Tahun 2012

\subsection{Pengujian Hipotesis}

Teknik analisis yang digunakan dalam penelitian ini adalah regresi berganda. Regresi linier berganda digunakan untuk menentukan hubungan antara variabel independen yaitu brand community terhadap terhadap variabel dependen $\mathrm{Y}$ yaitu loyalitas. Teknik analisis dilakukan dengan prosedur kerja:

1. Uji Asumsi Normalitas

2. Uji Asumsi Heteroskedastisitas

3. Uji Multikolinieritas

Hipotesis yang diajukan yaitu brand community (X) berpengaruh terhadap tingkat loyalitas (Y). 
Struktur Hubungan antara X dan Y diuji melalui analisis regresi berganda dengan hipotesis terdapat pengaruh yang signifikan antara brand community yang terdiri dari dua 3 variabel yaitu consciousness of kind $\left(\mathrm{X}_{1}\right)$, rituals and tradition $\left(\mathrm{X}_{2}\right)$, dan moral responsibility
$\left(\mathrm{X}_{3}\right)$ terhadap loyalitas (Y). Selanjutnya struktur hubungan diatas diterjemahkan kedalam hipotesis yang menyatakan pengaruh variabel bebas yang dominan terhadap variabel terikat. Untuk lebih jelas dapat dilihat pada Gambar 3.1 Berikut

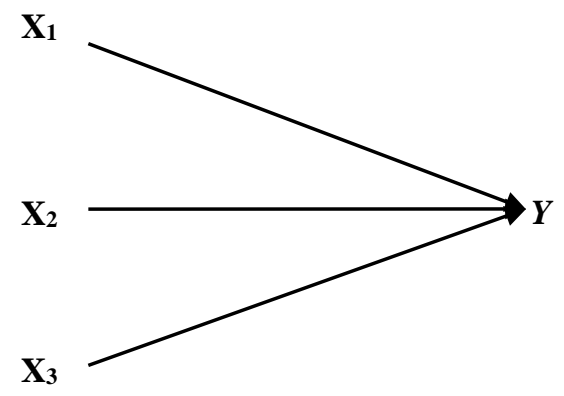

GAMBAR 3.1

DIAGRAN REGRESI BERGANDA HIPOTESIS UTAMA

\begin{abstract}
IV. HASIL PENELITIAN DAN PEMBAHASAN

4.1 Gambaran Brand Community Sahabat Museum Konperensi Asia Afrika

Sub variabel atau dimensi dari
brand community terdiri dari conciousness of kind, ritual and tradition, dan moral responsibility. Berdasarkan hasil pengolahan data dari kuesioner yang telah disebarkan, maka dapat dilihat hasil tanggapan pengunjung Museum Konperensi Asia Afrika berikut ini.
\end{abstract}

Brand community yang mendapatkan penilaian tertinggi yaitu pada program moral responsibility sebesar 44,66\%, hal ini dikarenakan dalam pelaksanaan moral responsibility disetujui pengunjung bahwa kegiatan wisata yang diselenggarakan oleh komunitas dapat meningkatkan rasa tanggung jawab untuk melestarikan Museum Konperensi Asia Afrika. Sedangkan sub variabel yang mendapatkan penilaian terendah yaitu consciousness of kind sebesar 21,30\%. Hal ini dikarenakan dalam pelaksanaan consciousness of kind dalam proses kegiatan brand community Sahabat Museum jarang yang merespon karena kurang memiliki rasa kedekatan terhadap para pengurus Museum/ staff Museum, akan tetapi mereka tetap aktif bertukar informasi mengenai kegiatan-kegiatan yang berhubungan dengan Museum Konperensi Asia Afrika melalui website, online, dan komunitas yang tidak hanya aktif di dalam lingkungan Museum Konperensi Asia Afrika.

Hasil penilaian tertinggi adalah Moral responsibility, hal ini disebabkan karena pengunjung memiliki tanggungjawab moral meliputi pecarian dan membantu anggota ataupun pengunjung lain dalam membangun citra Museum Konperensi Asia Afrika, seringnya kegiatan Sahabat Museum yang dilaksanakan Museum Konperensi Asia Afrika mampu membangun rasa tanggung jawab yang tinggi terhadap pengunjungnya. Hal ini memberikan kontribusi pada rasa kebersamaan dalam setiap pengunjung dan komunitas Sahabat Museum Konperensi Asia Afrika.

\subsection{Gambaran Loyalitas Pengunjung Museum Konperensi Asia Afrika}

Sub variabel atau dimensi dari loyalitas terdiri dari melakukan kunjungan secara teratur, kunjungan antar lini produk dan jasa, mereferensikan kepada orang lain, dan menunjukan kekebalan dari daya tarik produk sejenis dari pesaing. Berdasarkan hasil pengolahan data dari kuesioner yang telah disebarkan, maka dapat dilihat hasil tanggapan pengunjung Museum Konperensi Asia Afrika berikut ini.

Indikator dari loyalitas pengunjung yang mendapatkan penilaian tertinggi yaitu pada 
kunjungan antar lini produk dan jasa sebesar 29,65\%. Hal ini dikarenakan pada saat ini Museum Konperensi Asia Afrika sedang banyak diminati oleh pengunjung dengan alas an bahwa Museum Konperensi Asia Afrika memiliki layanan jasa edukasi yang bervariatif seperti French club, English club, mandarind club dan exhibition temporary (pameran sementara) sehingga pengunjung tidak merasa jenuh dengan program yang dilaksanakan Museum karena kegiatan yang dilaksanakan sesuai dengan kebutuhan pengunjung Museum Konperensi Asia Afrika.

\subsection{Pengaruh Brand Community} terhadap Loyalitas Pengunjung Museum Konperensi Asia Afrika

Pengujian hipotesis dilakukan untuk menguji dan mengetahui pengaruh brand community (X) terhadap loyalitas pengunjung (Y). brand community terdiri dari 3 sub variabel yaitu consciousness of kind $\left(\mathrm{X}_{1.1}\right)$, ritual and tradition $\left(\mathrm{X}_{1.2}\right)$ dan moral responsibility
$\left(\mathrm{X}_{1.3}\right)$ dilakukan dengan menggunakan uji statistik analisis regresi. Analisis regresi digunakan untuk mengetahui pengaruh variabel bebas terhadap variabel tidak bebas, serta mempunyai manfaat yang cukup besar bagi loyalitas pengunjung. Selanjutnya berdasarkan perhitungan statistik yang didasarkan pada angka-angka dari masing-masing variabel terlebih dahulu dilakukan transformasi, dimana dalam perhitungan transformasi dilakukan dengan program software SPSS 20 for windows. Secara lengkap hasil pengolahan data pengaruh brand community yang terdiri dari consciousness of kind, ritual and tradition, dan moral responsibility terhadap loyalitas pengunjung disajikan secara rinci sebagai berikut:

Selanjutnya berdasarkan perhitungan statistik yang didasarkan pada angka-angka dari masingmasing variabel terlebih dahulu dilakukan transformasi, dimana dalam perhitungan transformasi dilakukan dengan program yang ada dalam SPSS Versi 11,5. Secara lengkap hasil pengolahan data pengaruh brand community beserta tiga sub variabelnya terhadap loyalitas pengunjung Museum Konperensi Asia Afrika disajikan secara rinci dalam Tabel 4.1 sebagai berikut:

TABEL 4.1

MATRIK KORELASI ANTAR SUB VARIABEL BRAND COMMUNITY TERHADAP LOYALITAS PENGUNJUNG Correlations

\begin{tabular}{|c|c|c|c|c|c|}
\hline & & $\begin{array}{c}\text { conciousness } \\
\text { of kind }\end{array}$ & $\begin{array}{l}\text { ritual and } \\
\text { tradition }\end{array}$ & $\begin{array}{c}\text { moral } \\
\text { responsibility }\end{array}$ & loyalitas \\
\hline \multirow{4}{*}{ conciousness of kind } & Pearson Correlation & 1 & $.552^{* *}$ & $.696^{* *}$ & $.415^{* *}$ \\
\hline & Sig. (2-tailed) & & .000 & .000 & .000 \\
\hline & & 100 & 100 & 100 & 100 \\
\hline & Pearson Correlation & $.552^{* *}$ & 1 & $.606^{* *}$ & $.571^{* *}$ \\
\hline \multirow{2}{*}{ ritual and tradition } & Sig. (2-tailed) & .000 & & .000 & .000 \\
\hline & $\mathrm{N}$ & 100 & 100 & 100 & 100 \\
\hline \multirow{3}{*}{ moral responsibility } & Pearson Correlation & $.696^{* *}$ & $.606^{* *}$ & 1 & $.812^{* * *}$ \\
\hline & Sig. (2-tailed) & .000 & .000 & & .000 \\
\hline & $\mathrm{N}$ & 100 & 100 & 100 & 100 \\
\hline \multirow[t]{3}{*}{ loyalitas } & Pearson Correlation & $.415^{* *}$ & $.571 * *$ & $.812 * *$ & 1 \\
\hline & Sig. (2-tailed) & .000 & .000 & .000 & \\
\hline & $\mathrm{N}$ & 100 & 100 & 100 & 100 \\
\hline
\end{tabular}

**. Correlation is significant at the 0.01 level (2-tailed).

Sumber: Pengolahan data 2012

Berdasarkan hasil matrik korelasi antar sub variabel brand community, diperoleh hasil korelasi yaitu consciousness of kind $(0,415)$, ritual and tradition (0,571), dan moral responsibility $(0,812)$. moral responsibility memperoleh koefisien korelasi terbesar, hal ini 
menunjukkan bahwa antara moral responsibility dengan loyalitas pengunjung memiliki hubungan yang sangat kuat dibandingkan dengan conciousness of kind dan ritual tradition.

Rumusan hipotesis yang diajukan dalam penelitian ini adalah :

Ho:Pyx = 0: tidak ada pengaruh yang signifikan brand community terhadap loyalitas pengunjung Museum Konperensi Asia Afrika.

Ha:Pyx $\neq 0$ : terdapat pengaruh yang signifikan brand community terhadap loyalitas pengunjung Museum Konperensi Asia Afrika.

Dari hasil perhitungan dengan menggunakan SPSS 20, sebagai berikut:

1. Koefisien korelasi antara consciousness of kind (X1) dengan loyalitas pengunjung $\mathrm{r}=$ 0,415 , ini berarti terdapat hubungan yang sangat kuat antara consciousness of kind dengan loyalitas pengunjung. Jika diinterpretasikan korelasi consciousness of kind dengan loyalitas pengunjung adalah tinggi dan arahnya positif ini berarti apabila consciousness of kind baik maka loyalitas pengunjung akan meningkat.

2. Koefisien korelasi antara ritual and tradition (X2) dengan loyalitas pengunjung $\mathrm{r}=0,571 \mathrm{ini}$ berarti terdapat hubungan yang sangat kuat antara ritual and tradition dengan loyalitas pengunjung. Jika diinterpretasikan korelasi ritual and tradition dengan loyalitas pengunjung adalah rendah dan arahnya positif ini berarti apabila ritual and tradition baik maka loyalitas pengunjung akan meningkat.

3. Koefisien korelasi antara moral responsibility (X3) dengan loyalitas pengunjung $r=0,812$ ini berarti terdapat hubungan yang sangat kuat antara moral responsibility dengan loyalitas pengunjung. Jika diinterpretasikan korelasi moral responsibility dengan loyalitas pengunjung adalah rendah dan arahnya positif ini berarti apabila moral responsibility baik maka loyalitas pengunjung akan meningkat.

Untuk mengetahui seberapa kuat hubungan dan seberapa besar pengaruh program brand community yang terdiri dari consciousness of kind (X1), ritual and tradition (X2) dan moral responsibility (X3), dapat dilihat melalui nilai koefisien korelasi dan determinasi.

\section{TABEL 4.2 OUTPUT PENGARUH BRAND COMMUNITY LOYALITAS PENGUNJUNG MUSEUM KONPERENSI ASIA AFRIKA}

Model Summary

\begin{tabular}{|l|c|r|r|r|}
\hline Model & $\mathrm{R}$ & $\mathrm{R}$ Square & $\begin{array}{c}\text { Adjusted R } \\
\text { Square }\end{array}$ & $\begin{array}{c}\text { Std. Error of the } \\
\text { Estimate }\end{array}$ \\
\hline 1 & $.853^{\mathrm{a}}$ & .727 & .719 & 2.02541 \\
\hline
\end{tabular}

a. Predictors: (Constant), moral responsibility, ritual and tradition, conciousness of kind

Sumber : Hasil Pengolahan Data, 2012

Berdasarkan Tabel 4.2 hasil analisis menunjukkan bahwa nilai $\mathrm{R}=0,853$. Hal ini menunjukkan bahwa terdapat hubungan antara brand community yang terdiri dari consciousness of kind (X1), ritual and tradition (X2), dan moral responsibility (X3) terhadap loyalitas pengunjung $(\mathrm{Y})$ yaitu 0,853 . Maka termasuk kategori sangat kuat $(0,853$ $1,00)$, hal tersebut sesuai dengan interpertasi koefisien korelasi menurut sugiyono (2010:250).

Berdasarkan hasil perhitungan, nilai koefisien determinasi adalah 0,727 atau $72,7 \%$. Hal ini menunjukkan bahwa variabel brand community yang terdiri dari consciousness of kind (X1), ritual and tradition (X2), dan moral responsibility (X3) terhadap loyalitas pengunjung (Y) sebesar $72,7 \%$, sedangkan sisanya $27,3 \%$ dijelaskan oleh variabel lain yang tidak diteliti dalam penelitian ini.

\subsection{Pengaruh secara Simultan}

Secara simultan diperoleh nilai $\mathrm{F}_{\text {hitung }}=$ 85,272 sedangkan $F_{\text {tabel }}$ dengan derajat 
kebebasan pada $\alpha(0.05)$ adalah sebesar 1,44 Dengan demikian $\mathrm{F}_{\text {hitung }}(85,272)>\mathrm{F}_{\text {tabel }}(1,44)$ dengan nilai signifikansinya 0,000 . Nilai signifikansi lebih kecil dari taraf signifikansi $5 \%$, sehingga jelas $\mathrm{H} 0$ ditolak dan $\mathrm{Ha}$ diterima. Dengan nilai signifikansi 0,000 nilai signifikansi lebih kecil dari taraf signifikansi 5\% maka regresi dapat digunakan untuk memprediksi loyalitas pengunjung atau brand community berpengaruh terhadap loyalitas pengunjung pada taraf kepercayaan 95,5\%. Hipotesis dalam penelitian ini sebagai berikut : Ha $\neq 0$, Terdapat pengaruh yang signifikan kinerja program brand community berpengaruh terhadap loyalitas pengunjung.

Hal ini dapat dibuktikan dengan brand community yang diberikan Museum memberikan aspek pegalaman yang penting pada pengunjung, serta komponen yang penting bagi Museum untuk menilai sejauhmana bahwa pengunjungnya loyal. Perbedaan program dengan Museum lainnya menumbuhkan rasa bangga bagi pengunjung telah berkunjung ke Museum Konperensi Asia Afrika sehingga mereka ingin melakukan kunjungan ulang dan terciptanya pengunjung yang loyal.

\subsection{Pengaruh secara Parsial}

Penolakan terhadap Ho didukung secara parsial menunjukkan bahwa variabel bebas brand community yang terdiri dari, Berdasarkan hasil penelitian yang telah dilakukan dengan menggunakan analisa deskriptif dan verifikatif dengan menggunakan analysis regresi berganda mengenai program brand community terhadap loyalitas pengunjung Museum Konperensi Asia Afrika dapat diambil kesimpulan sebagai berikut.

1. Secara keseluruhan tanggapan pengunjung yang berpartisipasi dalam program Sahabat Museum mengenai variabel brand community yang terdiri dari consiousness of kind, ritual and tradition, dan moral responsibility memiliki penilaian yang berbeda-beda, setiap pengunjung memiliki pendapat yang berbeda dikarenakan kebutuhan setiap pengunjung berbeda satu dengan yang lainnya. Penilaian pengunjung mengikuti program brand community Sahabat Museum memperoleh penilaian consciousness of kind (X1), ritual and tradition (X2), dan moral responsibility (X3) memiliki pengaruh terhadap loyalitas pengunjung (Y). Hal ini berarti hipotesis yang diajukan diterima semua, dan dapat dijelaskan secara rinci sebagai berikut:

1. Terdapat pengaruh yang negatif atara sub variabel consciousness of kind (X1) terhadap loyalitas pengunjung sebesar $-4,482<1,44$ demikian juga nilai $\operatorname{sig}=0,000<0,05$ dengan nilai koefisien regresi $-0,342$.sehingga dapat dikatakan bahawa Ho ditolak Ha diterima.

2. Terdapat pengaruh yang signifikan atara sub variabel ritual and tradition (X2) terhadap loyalitas pengunjung sebesar 2,838>1,44, demikian juga nilai sig $=0,006<0,05$ dengan nilai koefisien regresi 0,195.sehingga dapat dikatakan bahawa Ho ditolak Ha diterima.

3. Terdapat pengaruh yang signifikan atara sub variabel moral responsibility (X3) terhadap keputusan menggunakan jasa golf sebesar 11,663>1,44 demikian juga nilai sig $=0,000<0,05$ dengan nilai koefisien regresi 0,932 sehingga dapat dikatakan bahawa Ho ditolak Ha diterima.

\section{KESIMPULAN}

yang tinggi pada sub variabel moral responsibility. Hal ini disebabkan karena pengunjung memiliki tanggungjawab moral meliputi pecarian dan membantu anggota ataupun pengunjung lain dalam meningkatkan loyalitas terhadap Museum Konperensi Asia Afrika, seringnya kegiatan Sahabat Museum yang dilaksanakan Museum Asia Afrika mampu membangun rasa tanggung jawab yang tinggi terhadap pengunjungnya. Hal ini memberikan kontribusi pada rasa kebersamaan dalam setiap pengunjung dan komunitas Sahabat Museum Konperensi Asia Afrika.

2. Tanggapan terhadap penilaian loyalitas pengunjung Museum Konperensi Asia Afrika terhadap variabel brand community, dilakukan untuk mengetahui sejauh mana pengunjung setia pada 
Museum Konperensi Asia Afrika dalam program brand community Sahabat Museum yang dilaksanakan oleh Museum Konperensi asia Afrika. Dimensi loyalitas terdiri dari dari melakukan kunjungan secara teratur, kunjungan antar lini produk dan jasa, mereferensikan kepada orang lain, dan menunjukan kekebalan dari daya tarik produk sejenis dari pesaing. Penilaian loyalitas paling besar yaitu pada dimensi kunjungan antar lini produk dan jasa. Hal ini menyimpulkan bahwa pada saat ini Museum Konperensi Asia Afrika sedang banyak diminati oleh pengunjung dengan alas an bahwa Museum Konperensi Asia Afrika memiliki layanan jasa edukasi yang bervariatif seperti French club, English club, mandarind club dan exhibition temporary (pameran sementara) sehingga pengunjung tidak merasa jenuh dengan program yang dilaksanakan Museum karena kegiatan yang dilaksanakan sesuai dengan kebutuhan pengunjung Museum Konperensi Asia Afrika.

3. Berdasarkan pengujian hipotesis secara simultan menunjukan bahwa variabel brand community memiliki pengaruh yang signifikan terhadap loyalitas. Sedangkan pengujian hipotesis secara parsial menunjukan brand community yang terdiri dari consiousness of kind, ritual and tradition, dan moral responsibility memiliki pengaruh yang berbeda. Sub variabel consciousness of kind berpengaruh negatif terhadap loyalitas, secara parsial tidak memiliki pengaruh yang signifikan terhadap loyalitas. Dimana dapat disimpulkan bahwa semakin rendah persepsi pengunjung terhadap consciousness of kind maka loyalitas juga mengalami penurunan, hal ini menyatakan arah hubungan yang negatif, dimana penurunan variabel consiousness of kind akan mengakibatkan penurunan loyalitas. Sedangkan ritual and tradition, dan moral responsibility berpengaruh positif, dan memiliki pengaruh yang signifikan terhadap loyalitas.

\section{DAFTAR PUSTAKA}

Aaker, David. 1991. Managing Brand Equity; Capitalizing on the Value of Value of Brand Name. New York: Free Pass

Ali Hasan. 2009. Marketing. Yogyakarta: Media Pressindo.

Berry, leonard L. dan Parasuraman. 1991. Marketing Service. New York: Three Press

Fandy Tjiptono. 2009. Brand Management \& Strategy, Yogyakarta: Andi Offset.

Fandy Tjiptono. 2008. Pemasaran Jasa, Jawa Timur: Bayumedia.

Griffn, Jill. 2009. Customer Loyalty: Menumbuhkan dan Mempertahankan Kesetiaan Pelanggan. Jakarta: Erlangga.

Kotler, Philip. 2008. Marketing Management. Prentice Hall: Upper Saddle River, $\mathrm{Nj}$.

Kotler Philip, Kevin Lane Keller. 2007. Manajemen pemasaran Edisi 12. Jakarta: PT. Indeks Kelompok Gramedia.

Harun Al Rasyid. 1994. Teknik Penarikan Sampel dan Penyusunan Skala. Bandung

Hermawan Kartarajaya. 2005.Markplus On Strategy. Jakarta: PT Gramedia.

Husein umar. 2009. Metode Penelitian Untuk Skripsi dan Tesis Bisnis Edisi Kedua. Jakarta: Rajawali Pers.

Hurriyati Ratih. 2010. Bauran pemasaran dan Loyalitas Konsumen. Bandung: Alfabeta

Kotler, Neil G, Philip Kotler, Wendy I Kotler. 2008. Museum Marketing and

Strategy. 2nd Edition. San

Fransisco: John Wiley \& Sons.

Kotler, Philip, and Keller. 2008. Marketing Management: $13^{\text {th }}$ edition. New Jersey: Prentice Hall. and Keller. 2009. Marketing Management: $13^{\text {th }}$ edition. New Jersey: Prentice Hall.

Maholtra, Naresh K. 2005. Riset Pemasaran, Pendekatan Terapan edisi ke-4 Jilid 1. Jakarta: PT. Indeks Gramedia.

Morrisson. 2002. Hospitality and Travel Marketing: $13^{\text {th }}$ edition. Delmar: Thomson Learning.

Oka A. Yoeti. 2002. Tours and Travel Marketing. Jakarta:Pradnya Paramita. 
Oka A. Yoeti. 2001. Perencaanaan Strategis Pemasaran Daerah Tujuan Wisata. Jakarta: Pradnya Paramita

PB. Triton. 2005. Paradigma Baru Manajemen Sumber Daya Manusia. Yogyakarta: Tugupublisher. Cetakan 1.

Schiffman \& Kanuk. 2004. Perilaku Konsumen(edisi 7). Jakarta: Prentice Hall

Sekaran, Uma. 2006. Reseach Methods For Business. Edisi 4. Jakarta: Salemba Empat.

Sugiyono. 2008. Statistik Untuk Penelitian. Bandung: Alfabeta.

Sugiyono. 2010. Metode Penelitian Bisnis, Bandung: Alfabeta.

Suharsimi Arikunto. 2009. Prosedur Penelitian Suatu Pendekatan Praktek. Jakarta: Rineka Cipta.

Suharsimi Arikunto. 2006. Prosedur Penelitian Suatu Pendekatan Praktek. Yogyakarta: Bina Aksara.

Suliyanto. 2005. Meode Riset Bisnis. Yogyakarta: Andi

Vanessa Gaffar. F. 2007. Customer Relationship management and Marketing public Relations. Bandung: Alfabeta

Wahid Sulaiman. 2004. Analisis-Analisis Regresi Menggunakan SPSS. Yogyakarta: Andi.

JURNAL:

Albert M. Muniz, Jr \& Thomas C. O’Guinn. 2001. Brand Community. Journal of Consumer Research.

Chaudry, Karan \& Krishnan, Venkat R. 2007. Impact of Corporate Social Responsibility and Transformational Leadership on Brand Community. Sage Publication.

Damián Stamor and Kimberly Lerdall. 2010. Managing Heritage Voiunteers: An Expioratory Study of Voiunteer Programmes in Art Museums Worldwide. Pp.300-367.

Damian Stamor dan Kimberly Lerd. 2008. Journal Of Heritage Tourism, p.206208.

Corey, Dominic. 2009. Tourists Buy the Idea of Destination Branding Disertation -Destination Branding, The new
Concept in Tourism development. www.dissertation-help.co.uk.

Davidson, McNeil \& Ferguson. 2007. "Brand Community in Magazine Consumption. Intrnational Journal of Sociology and Social Policy.

Elena Y. Ilancehenko. 2005. Exploring Culture, History and Nature as Tourist Destination Branding Constructs:The Case of A Peripheral Region in Sweden.

Fajar Martha kusumah. 2020. Analisis Pengaruh Brand Community Terhadap Loyalitas Merek Pada pengguna Honda Mega Pro di Surakarta. Semarang; universitas diponegoro.

Fischer, Brown RJ. 2001. Explaining Intergroup Differentiation in a Community Psycology. San Fransisco: Journal of psicology

Goeldner, C.R., Ritchie, J.R.B., \& MacIntosh, R. W. 2000. Tourism: Princioles, Practice, Philosophies, $8^{\text {th }}$ ed. NewYork. John Wiley \& Sons, Inc

Goodlad dan Mclvor. 2008. Journal of Heritage Tourism, p.203.

Hull dan Hooper Greenhill. 2010. A New Leaflet For The Service or The Beginnings of a Marketing Strategy, p7 p24.

Lord, Gail Dexter and Lord, Barry. 2000. The Manual of Museum Management, Proffessional Museum and Heritage Serise. London. The Stationary Office (third impression).

Morgan N, Pritchard Annete and Pride, Roger. 2004. Destiation Branding: Creating The Unique destination proportion, Secon Edition. London: Elsevier Butterworth-Heinemann.

Purbaningtyas, Retno. 2009. Pengaruh Brand Community Terhadap Loyalitas Merek Studi Kasus pada Komunitas Motor Jakarta Mio Club. Skripsi. Universitas Indonesia.

Saila Saraniemi. 2009. Destination In A Country Context A Case Study of Finland In the British Market. University of Joensuu Faculty of law, Economics and Business Administration. 
Wiegandt, Philipp. 2009. Value Creation of Firm-Establish Brand Community. University of Munchen.

Zeithhaml, Valerie A. \& Bitner. 2005 Service Marketing edition: Integrating Cutomer Focus. Newyork: Mc Graw Hill Inc.

www.demokratnews.com

www.skompas.com

http://padmanaba.or.id

http://cintamuseum.blogspot

http://foldmagazine.com

www.museumfriends.com

www.UNWTO.com

www.internationaolcouncilofmuseum.com 